\title{
HELMINTH INFECTIONS ACROSS A NORTHERN BOBWHITE (COLINUS VIRGINIANUS) ANNUAL CYCLE IN FISHER COUNTY, TEXAS
}

\author{
Stacie M. Villarreal ${ }^{1,3}$, Andrea Bruno ${ }^{1}$, Alan M. Fedynich ${ }^{1,4}$, \\ Leonard A. Brennan ${ }^{1}$, and Dale Rollins ${ }^{2}$
}

ABstRaCT.-Northern Bobwhite (Colinus virginianus) populations in Texas have been declining during the past several decades. Declines have been attributed to habitat loss, but other causes and potential contributing factors (e.g., parasites, disease) have been posited. Little is known about helminth parasites in bobwhites from Texas. Previous studies often used bobwhites collected during the hunting season, which only samples individuals that survive after the summer breeding season. Our objectives were to (1) assess the prevalence, intensity, and abundance of helminths in bobwhites from Fisher County, Texas, during an annual cycle; (2) identify which species are known to be pathogenic; and (3) determine whether infections are related to host age, sex, and season of collection. We collected 142 bobwhites during February-March $2010(n=37)$, August $2010(n=51)$, and December 2010-January $2011(n=54)$. We found 7 helminth species, of which 3 (Oxyspirura petrowi, Tetrameres pattersoni, and Dispharynx nasuta) are known to cause tissue damage to bobwhites. Aulonocephalus pennula was the most common (82\% prevalence) and numerically abundant species (96\% of all specimens). Prevalence and mean abundance of A. pennula, O. petrowi, and T. pattersoni were higher in adults than juveniles. Prevalence of A. pennula, O. petrowi, and T. pattersoni did not vary with host sex. Mean abundance of T. pattersoni was higher in females than males. Prevalence of A. pennula, O. petrowi, and T. pattersoni was lower in summer than early and late winter and was related to low infections in young juveniles. Our findings provide insight into helminth infection dynamics of Northern Bobwhites across an annual cycle.

REsumen.-Las poblaciones de codorniz norteña (Colinus virginianus) en Texas han disminuido durante las últimas décadas. En general, las disminuciones se han atribuido a la pérdida del hábitat, pero también se han planteado otros factores que podrían contribuir (como parásitos, enfermedades, etc.). Sabemos poco sobre los parásitos helmintos en las codornices de Texas. A menudo, estudios previos han utilizado codornices colectadas durante la temporada de caza, lo que muestrea sólo aquellos individuos que sobrevivieron la temporada de reproducción del verano. Nuestros objetivos fueron (1) evaluar la prevalencia, intensidad y abundancia de helmintos en codornices en el condado de Fisher, Texas, durante un ciclo anual, (2) identificar qué especies se sabe que son patógenas, y (3) determinar si las infecciones están relacionadas con la edad, el sexo del hospedero y con la temporada de colecta. Colectamos 142 codornices durante febrero-marzo del $2010(n=37)$, agosto del $2010(n=51)$ y diciembre del 2010 a enero del $2011(n=54)$. Encontramos 7 especies de helmintos de las cuales 3 (Oxyspirura petrowi, Tetrameres pattersoni y Dispharynx nasuta) son conocidas por causar daños en los tejidos de las codornices. Aulonocephalus pennula fue la más común (un $82 \%$ de prevalencia) y abundante $(96 \%$ de todas las muestras) de las especies. La prevalencia y la abundancia media de A. pennula, O. petrowi y T. pattersoni fueron mayores en los adultos que en los juveniles. La prevalencia de A. pennula, O. petrowi y T. pattersoni no varió con el sexo del hospedero. La abundancia promedio de T. pattersoni fue mayor en las hembras que en los machos. La prevalencia de A. pennula, O. petrowi y T. pattersoni fue menor en verano que en invierno y se relacionó con infecciones leves en ejemplares jóvenes. Nuestros resultados proporcionan una idea sobre la dinámica de las infecciones por helmintos en las codornices del norte a lo largo del ciclo anual.

The Northern Bobwhite (Colinus virginianus; hereafter, bobwhite) is a popular game bird in Texas, but its populations have been declining for more than 4 decades. These population declines have been attributed to habitat loss (Hernández et al. 2013). However, Peterson (2007) commented that parasites may play a role in population declines and suggested more information was needed on this topic.
One of the few regions where bobwhites have maintained abundant populations is the Rolling Plains of Texas (Rollins 2007). However, our knowledge of the parasite community in this region is limited to a study that included an unknown number of bobwhites from Coleman County in a sample of 14 individuals from central Texas (Webster and Addis 1945); a study that examined 605 bobwhites for eyeworms, 229 for eye and breast muscle

\footnotetext{
${ }^{1}$ Caesar Kleberg Wildlife Research Institute, 700 University Blvd., Texas A\&M University-Kingsville, Kingsville, TX 78363.

${ }^{2}$ The Rolling Plains Quail Research Foundation, Box 61517, San Angelo, TX 76906.

3Present address: Texas A\&M AgriLife Extension Service, 846 6th St., Hempstead, TX 77445

${ }^{4}$ Corresponding author. E-mail: alan.fedynich@tamuk.edu
} 
nematodes, and 47 for eye, breast, and intestinal nematodes (Jackson and Green 1965); and a study of 151 bobwhites (Jackson 1969) in which completeness of necropsy methods was unclear. In addition, several recent studies have focused exclusively on eyeworms (Dunham et al. 2014, Bruno et al. 2015), which does not provide insight about the helminth community. Consequently, it is unknown what helminth species currently infect bobwhites within the Rolling Plains and whether there are pathogenic species present.

Evidence from studies conducted in northern Florida suggest that host age influences parasite infections of bobwhites (Moore et al. 1987, Davidson et al. 1991). Historically, studies have used samples collected only during the hunting season which results in a sample of individual quail that have already survived various parasite challenges. Therefore, it is necessary to collect young juveniles (6-10 weeks old), older juveniles ( $>10$ weeks old), and adults to examine host age within the context of seasonal infections. Our objectives were to determine species of helminth parasites infecting bobwhites in Fisher County, Texas; identify species known to be pathogenic; and determine whether prevalence and abundance of helminths vary with host age, host sex, and season.

\section{METHODS}

We collected 142 bobwhites (45 adult males, 23 adult females, 37 juvenile males, and 37 juvenile females) in Fisher County, Texas, at the Rolling Plains Quail Research Ranch (RPQRR) (32 $\left.43^{\prime} 14.65^{\prime \prime} \mathrm{N}, 100^{\circ} 32^{\prime} 49.89^{\prime \prime} \mathrm{W}\right)$ and a nearby private ranch located $22.5 \mathrm{~km}$ east of the RPQRR ( $\left.32^{\circ} 43^{\prime} 9.01^{\prime \prime} \mathrm{N}, 100^{\circ} 19^{\prime} 15.01^{\prime \prime} \mathrm{W}\right)$. The RPQRR is a nonprofit research ranch. These ranches are approximately 1902 ha and 1416 ha in size, respectively.

There were 3 collection periods: late winter (February-March 2010; 25 adults and 12 old juveniles $>10$ weeks old), summer (August 2010; 22 adults and 29 young juveniles $6-10$ weeks old), and early winter (December 2010 January 2011; 21 adults and 33 old juveniles $>10$ weeks old). These time intervals were selected so that the critical periods (i.e., birds surviving the winter and entering the breeding season, summer breeding season, and birds entering the winter season) of the annual host cycle could be assessed for helminths. We did not collect during the nesting season (April-July).

We collected bobwhites by shooting during the hunting season (opportunistically using hunter-shot birds) and by shooting under the auspices of a scientific collection permit outside of the hunting season (Texas Parks and Wildlife Department; permit SPR-1209-400). We determined the sex of each host by using the coloration of feathers on the head. Age of juveniles and adults was determined by examining the primary wing coverts (Jackson 1969). We classified flight-capable juveniles as young juveniles if they were collected in August (6-10 weeks old) and as old juveniles if they were collected during February-March or December-January (>10 weeks old). Each bird was transported from the field in an individually numbered plastic freezer bag on ice and later frozen. Birds were necropsied, and parasites were processed and identified as outlined in Villarreal (2012). Since most of the cestode samples were deteriorated and scolices were often missing, species could not be readily identified or direct counts made. Therefore, multiple cestode fragments found in which genus could be determined were counted as one cestode individual per bird. Representative specimens were deposited in the U.S. National Parasite Collection, Beltsville, MD: Aulonocephalus pennula (105783), Oxyspirura petrowi (105784), Tetrameres pattersoni (105785), and Dispharynx nasuta (105786). Parasitological terms of prevalence, intensity of infection, abundance, mean abundance, infracommunity, and component community follow Bush et al. (1997).

We used chi-square analysis to compare the prevalence of parasite species that occurred $\geq 25 \%$ for the main effects variables of host age, sex, and season of collection. To account for the aggregated count data, we used a generalized linear mixed model fitted with the negative binomial distribution (PROC GLIMMIX) in SAS 9.3 software (SAS Institute Inc., Cary, NC). We sought to determine whether abundance of the parasites varied by the main (age, sex, and season) and relevant interaction effects variables (age * sex and age * season). We used backward selection based on type III effects $F$ tests to eliminate terms where $P>$ 0.05 until only significant effects remained. The type III effects test the significance of an 
TABle 1. Prevalence values (number of infected and percentage infected), intensity values (mean [SE]), range, abundance (mean [SE]), and total for helminths from 142 Northern Bobwhites (Colinus virginianus) collected from Fisher County, Texas, during 2010-2011.

\begin{tabular}{|c|c|c|c|c|c|}
\hline \multirow[b]{2}{*}{ Helminth species } & \multirow{2}{*}{$\frac{\text { Prevalence }}{\text { No. }(\%)}$} & \multicolumn{2}{|c|}{ Intensity } & \multicolumn{2}{|c|}{ Abundance } \\
\hline & & Mean (SE) & Range & Mean (SE) & Total \\
\hline Aulonocephalus pennula $(\mathrm{C}, \mathrm{SI}, \mathrm{L})^{\mathrm{a}}$ & $117(82)$ & $134.3(11.2)$ & $2-518$ & $110.7(10.2)$ & 15,716 \\
\hline Oxyspirura petrowi $(\mathrm{E})$ & $67(47)$ & $5.6(0.7)$ & $1-23$ & $2.6(0.4)$ & 373 \\
\hline Tetrameres pattersoni $(\mathrm{P})$ & $37(26)$ & $2.9(0.3)$ & $1-8$ & $0.8(0.1)$ & 108 \\
\hline Dispharynx nasuta $(\mathrm{P})$ & $1(0.7)$ & 1 & 1 & $<0.1(<0.1)$ & 1 \\
\hline Acanthocephalan larvae (N) & $26(18)$ & $4.3(1.7)$ & $1-43$ & $0.8(0.3)$ & 113 \\
\hline Cestode spp. ${ }^{\mathrm{b}}(\mathrm{SI})$ & $13(9)$ & - & - & - & 13 \\
\hline
\end{tabular}

effect when all other effects are included in the specified model. We used least-squares means to compare significant effects among variables. Statistical significance was inferred at $P \leq 0.05$. Descriptive statistics are presented as the mean \pm 1 standard error $(\mathrm{SE})$.

\section{REsults}

We found 7 species of helminths (4 nematodes, 1 acanthocephalan larva, and 2 cestodes) representing 16,324 helminth individuals (Table 1). We found helminths in 6 microhabitats: under the nictitating membrane of the eye and in neck muscle, proventriculus, small intestine, large intestine, and ceca (Table 1).

Overall, $15 \%$ of the bobwhites were not infected, 28\% were infected with 1 species, $30 \%$ with 2 species, $21 \%$ with 3 species, $5 \%$ with 4 species, and $1 \%$ with 5 species. Nematodes were the most abundant taxon (Table 1). The most prevalent and numerically abundant species was A. pennula (82\% prevalence and $96 \%$ of all worm individuals), followed by $O$. petrowi $(47 \%$ and $2 \%)$ and T. pattersoni $(26 \%$ and $0.7 \%$ ). All of the remaining species had $<19 \%$ prevalence and contributed $<1 \%$ of worms (Table 1). Cestodes (Rhabdometra odiosa and Raillietina spp.) occurred in 13 (9\%) birds (Table 1).

\section{Influence of Host Age}

Prevalence of $A$. pennula in adults and old juveniles was greater $(P<0.0001)$ than in young juveniles $(97 \%, 100 \%$, and $21 \%$, respectively), whereas prevalence of $O$. petrowi and T. pattersoni were greater $(P<0.0001$ for each species) in adults (68\% and $43 \%$, respectively) than in old juveniles $(42 \%$ and $18 \%$, respectively) and young juveniles (7\% and $0 \%$, respectively; Table 2). An interaction between host age and sex was found for mean abundance of $A$. pennula $(P=0.0004)$. Mean abundance of $A$. pennula was similar between adult males and females and old juvenile males and females but was lower in young juvenile males than females $(P<0.0001)$. Mean abundance of $O$. petrowi was similar between adults and old juveniles but was lower $(P<0.0001)$ in young juveniles. Mean abundance of $T$. pattersoni was higher $(P<$ $0.0001)$ in adults than old juveniles; T. pattersoni was not found in young juveniles.

\section{Influence of Host Sex}

Prevalence of A. pennula, O. petrowi, and T. pattersoni did not vary by host sex. We found no differences between host sex and mean abundance of O. petrowi. Mean abundance of $T$. pattersoni was higher $(P=0.0051)$ in females compared to males. The influence of host sex on A. pennula was significant only within young juveniles as explained above.

\section{Influence of Season}

All bobwhites were infected with at least one parasite species in the late-winter collection; $59 \%$ were infected with 1-2 species and $41 \%$ were infected with 3-4 species. In summer, $33 \%$ were infected with 1-2 species and $24 \%$ were infected with 3-4 species, but these numbers were influenced by lack of infections in young juveniles (Table 3 ). In the early winter collection, $80 \%$ were infected with 1-2 species and $20 \%$ were infected with 3-5 species.

Variation in prevalence (late winter, summer, early winter) occurred for A. pennula $(P$ $<0.0001 ; 100 \%, 55 \%$, and $96 \%$, respectively), O. petrowi $(P=0.0137 ; 65 \%, 33 \%, 48 \%)$, and T. pattersoni $(P=0.0215 ; 43 \%, 20 \%, 20 \%)$. 

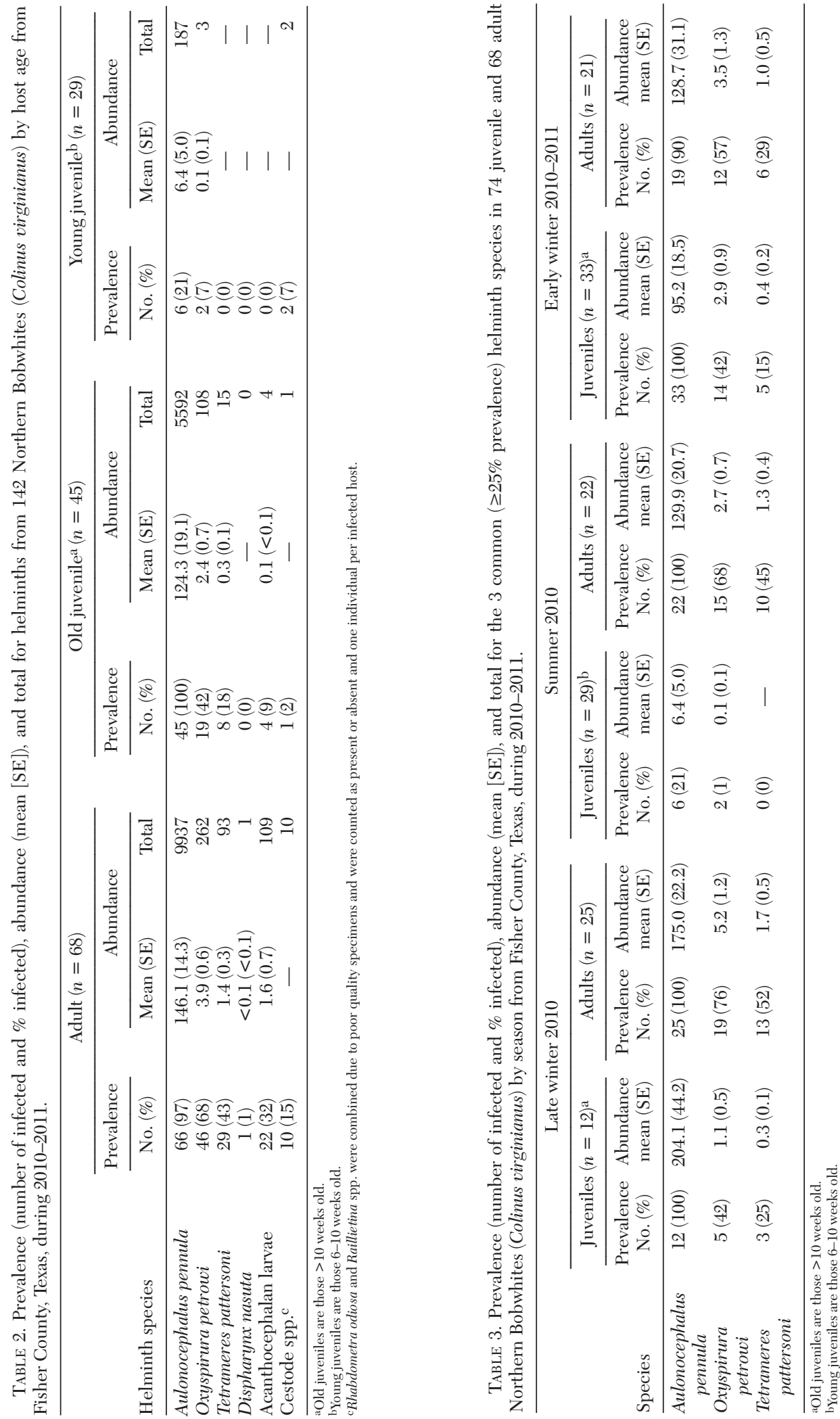
However, mean abundance of $A$. pennula, $O$. petrowi, and T. pattersoni did not vary by season.

\section{Discussion}

We found depauperate helminth infracommunities, ranging from 1 to 5 species, in which the most common was 2 helminth species $(30 \%)$ within an individual. The component community consisted of 7 species, all with indirect life cycles, and was dominated by A. pennula. In contrast, studies conducted in the eastern and southeastern United States found wild bobwhites to have species-rich ( $\geq 19$ species) helminth communities including species with direct and indirect life cycles (Cram et al. 1931, Davidson et al. 1982, Forrester and Spalding 2003). The reason for these different findings is unclear, but a likely factor is different precipitation regimes between geographic regions, where drier conditions may negatively influence intermediate host population dynamics and limit parasites with direct life cycles (Gray et al. 1978).

Oxyspirura petrowi and T. pattersoni occurred in $\geq 25 \%$ prevalence. Localized tissue damage and inflammation have been reported for T. pattersoni (Davidson et al. 1991) and O. petrowi (Bruno et al. 2015). We probably undercounted $O$. petrowi by examining only the eye surface and underneath the eyelid and nictitating membrane because recent reports indicate that $O$. petrowi also occurs in the lacrimal duct, lacrimal gland, and Harderian gland (Dunham et al. 2014, Bruno et al. 2015).

We report for the first time T. pattersoni and D. nasuta in Northern Bobwhites from the Rolling Plains ecoregion of Texas. Tetrameres pattersoni is thought to be more pathogenic than Tetrameres americana (Peterson 2007), and D. nasuta is considered the most pathogenic of the 15 species of Dispharynx (Carreno 2008). Unfortunately, studies have not been conducted to determine whether T. pattersoni and $D$. nasuta have an impact at the host population level.

\section{Influence of Host Age}

Young juvenile bobwhites had few or no helminth species, whereas old juveniles and adults had helminth communities that were similar in species richness. Prevalence and abundance of the 3 common species tended to be related to host age. Some bobwhite parasite studies have shown host age to influence some species of helminths (Davidson et al. 1991), whereas other studies have not (Forrester et al. 1984, Moore et al. 1987). Parmalee (1952) found no difference between host age and parasitism in bobwhites from Texas. Based on our findings, bobwhites are accumulating both species and individuals of species as they transition from hatch-year birds to adults.

\section{Influence of Host Sex}

Host sex was not an important factor in prevalence or abundance of $O$. petrowi, indicating that both sexes are similarly exposed to infective stages of this helminth. However, mean abundance of $A$. pennula was higher in young juvenile females than in the other agesex categories, and mean abundance of $T$. pattersoni was higher in females than males. Our results are generally consistent with the findings of other studies in which host sex has little or no influence on helminth prevalence or intensity of infection (Forrester et al. 1984, Demarais et al. 1987, Moore et al. 1987, Davidson et al. 1991). Of the 15 species found in bobwhites from Florida by Davidson et al. (1991), 2 nematodes (Cyrnea colini and Heterakis isolonche) were higher in females than males.

\section{Influence of Season}

Several studies report a seasonal effect in particular species of helminths, in which prevalence, intensity, or abundance vary (Hansen and Robel 1972, Davidson et al. 1980, Demarais et al. 1987). Davidson et al. (1980) demonstrated that certain species tend to increase with time, whereas others remain relatively stable or fluctuate erratically. In our study, fewer bobwhites were infected with $A$. pennula, O. petrowi, and T. pattersoni in the summer than in late winter or early winter. This pattern was strongly influenced by young juveniles, which had few to no helminths.

In a methodological change from previous studies, we separated juveniles into 2 categories (6-10 weeks old and >10 weeks old). We believe this classification clarified the infection pattern wherein young juveniles started to become infected (69\% did not acquire infections and those that did had 1 or 2 species), compared to old juveniles where helminth community pattern and structure were more similar to that found in adults. This finding underscores the importance of subclassifying 
juveniles for a better understanding of how helminth communities develop in specific host age classes and also demonstrates that sampling during the winter hunting season likely provides the best snapshot of overall helminth community composition in bobwhites.

\section{ACKNOWLEDGMENTS}

Our study was funded by the Rolling Plains Quail Research Foundation. We are grateful to the Rolling Plains Quail Research Ranch and P. Melton for making this research possible. LAB was supported by the C.C. Winn Endowed Chair for Quail Research. We also thank L. LaCoste, B.A. Koennecke, and other workers at the Rolling Plains Quail Research Ranch for field assistance and B. Lolley and C. Mercer for laboratory assistance. We thank D. Pence, PhD, Texas Tech University Health Science Center, Lubbock, Texas, and M. Kinsella, PhD, Missoula, Montana, for assistance with helminth identifications. This is manuscript No. 16-114 of the Caesar Kleberg Wildlife Research Institute.

\section{Literature Cited}

Bruno, A., A.M. Fedynich, A. Smith-Herron, and D. RoLLINS. 2015. Pathological response of Northern Bobwhites to Oxyspirura petrowi infections. Journal of Parasitology 101:364-368.

Bush, A.O., K.D. Lafferty, J.M. Lotz, and A.W. Shostak. 1997. Parasitology meets ecology on its own terms: Margolis et al. revisited. Journal of Parasitology 83:575-583.

Carreno, R.A. 2008. Dispharynx, Echinuria, and Streptocara. Pages 326-342 in C.T. Atkinson, N.J. Thomas, and D.B. Hunter, editors, Parasitic diseases of wild birds. Wiley-Blackwell, Ames, IA.

Cram, E.B., M.F. Jones, and E.A. Allen. 1931. Internal parasites and parasitic diseases of the bobwhite. Pages 229-313 in H.L. Stoddard, editor, The bobwhite quail: its habits, preservation and increase. Charles Scribner's Sons, New York, NY.

Davidson, W.R., F.E. Kellogg, and G.L. Doster. 1980. Seasonal trends of helminth parasites of bobwhite quail. Journal of Wildlife Diseases 16:367-375.

Davidson, W.R., F.E. Kellogg, and G.L. Doster. 1982. An overview of disease and parasitism in southeastern bobwhite quail. Pages 57-63 in F. Schitoskey Jr., E.C. Schitoskey, and L.G. Talent, editors, Proceedings of the Second National Bobwhite Quail Symposium, Oklahoma State University, Stillwater, OK

Davidson, W.R., F.E. KellogG, G.L. Doster, and C.T. MoORE. 1991. Ecology of helminth parasitism in bobwhites from northern Florida. Journal of Wildlife Diseases 27:185-205.
Demarais, S., D.D. Everett, and M.L. Pons. 1987. Seasonal comparison of endoparasites of Northern Bobwhites from two types of habitat in southern Texas. Journal of Wildlife Diseases 23:256-260.

Dunham, N.R., L.A. Soliz, A.M. Fedynich, D. Rollins, AND R.J. KENDALL. 2014. Evidence of an Oxyspirura petrowi epizootic in Northern Bobwhites (Colinus virginianus), Texas, USA. Journal of Wildlife Diseases 50:552-558.

Forrester, D.J., J.A. Conti, A.O. Bush, L.D. Campbell, AND R.K. FrOHLICH. 1984. Ecology of helminth parasitism of bobwhites in Florida. Proceedings of the Helminthological Society of Washington 51:255-260.

Forrester, D.J., AND M.G. Spalding. 2003. Northern Bobwhites. Pages 513-548 in Parasites and diseases of wild birds in Florida. University Press of Florida, Gainesville, FL.

Gray, G.G., D.B. Pence, and C.D. Simpson. 1978. Helminths of sympatric Barbary sheep and mule deer in the Texas Panhandle. Proceedings of the Helminthological Society of Washington 45:139-141.

Hansen, M.F., and R.J. Robel. 1972. Seasonal changes and habitat influencing helminthiasis in bobwhite quail. Pages 350-356 in J.A. Morrison and J.C. Lewis, editors, Proceedings of the First National Bobwhite Quail Symposium. Oklahoma State University, Stillwater, $\mathrm{OK}$.

Hernández, F., L.A. Brennan, S.J. DeMaso, J.P. Sands, AND D.B. Wester. 2013. On reversing the Northern Bobwhite population decline: twenty years later. Wildlife Society Bulletin 37:177-188.

JACKSON, A.S. 1969. A handbook for bobwhite quail management in the west Texas Rolling Plains. Texas Parks and Wildlife Department, Austin, Bulletin No. 48.

JaCKson, A.S., AND H. Green. 1965. Dynamics of bobwhite quail in the west Texas Rolling Plains: parasitism in bobwhite quail. Federal Aid Project No. W-88-R-4. Texas Parks and Wildlife Department, Austin, TX.

Moore, J., M. Freehling, D. Horton, and D. Simberloff. 1987. Host age and sex in relation to intestinal helminths of bobwhite quail. Journal of Parasitology 73:230-233.

Parmalee, P.W. 1952. Ecto- and endoparasites of the bobwhite: their numbers, species, and possible importance in the health and vigor of quail. North American Wildlife Conference 17:174-188.

Peterson, M.J. 2007. Diseases and parasites of Texas quails. Pages 89-114 in L.A. Brennan, editor, Texas quails: ecology and management. Texas A\&M University Press, College Station, TX.

Rollins, D. 2007. Quails on the Rolling Plains. Pages 117-141 in L.A. Brennan, editor, Texas quails: ecology and management. Texas A\&M University Press, College Station, TX.

VillarReal, S.M. 2012. Helminth infections across the annual breeding cycle of Northern Bobwhites from Fisher County, Texas. Master's thesis, Texas A\&M University-Kingsville, Kingsville, TX.

Webster, J.D., AND C.J. ADDIs. 1945. Helminths from the bob-white quail in Texas. Journal of Parasitology $31: 286-287$.

Received 10 February 2016 Accepted 6 May 2016 